\title{
The British National Bibliography and Some Random Impressions of a Fulbrighter in England
}

$M r$. Rush, librarian of the University of Wyoming, was in England on a Fulbright award for the year 1952-53.

$\mathrm{O}$ N JANUARY 4, I950, appeared the first number of a publication now widely known in England as the BNB. The three years of activity and service by the British National Bibliography probably constitute the greatest cooperative undertaking in the field of bibliography since the year 1876 , when the ALA took over Poole's Index which project eventually developed into the Wilson indexes. It would seem without doubt that the BNB bibliographical adventure constitutes one of the most progressive steps taken by the English library profession since the end of the war. The $\mathrm{BNB}$ is bringing about many of the library services which have been needed in Great Britain and has laid the groundwork for even greater achievements.

From the subscription records in the editor's office it would seem that BNB is not as well-known in America as it should be, and certainly American libraries would profit by making more use of its services.

The ideas behind its foundation, its present activities, and its future possibilities are one of the best examples of effective cooperation in the library profession known to me in contemporary library activities. A glance, for example, at the impressive. list of names joined together to produce the BNB will bear this out-the Library Association, the British Museum, ASLIB, the
Booksellers' Association, the British Council, the National Book League, the National Central Library and the UNESCO Cooperating Body for Libraries. Out of these groups a Council was formed to put into action a publication for "publishing in appropriate bibliographical form lists of books, pamphlets and other recorded material of whatever nature published in Great Britain, the Dominions and Colonies and/or foreign countries, together with such annotations or further information as may be desirable for the use of libraries, bibliographers and others." The actual administration of the work was left in the hands of an executive committee, which is made up of one representative each from the British Museum, the Library Association, the Publishers' Association, the Booksellers' Association and the National Book League.

The BNB meets the librarian's need for an up-to-date and full list of current copyrighted publications in Great Britain. It has been well received in Great Britain and subscriptions have exceeded original estimates. It is published weekly and a special edition is available which is printed on one side of the page only to allow for cutting up and mounting onto cards if desired. A few libraries are finding this arrangement most convenient and useful. The entries in BNB are arranged in subject groups and are classified according to Dewey as well as entered according to the Anglo-American cataloging code. A great time-saving feature is the serial number which libraries merely quote 
when requesting many interlibrary loans and for reporting to the regional union catalogs and the National Central Library their acquisitions and withdrawals. The weekly and monthly numbers contain an author index giving short titles, publisher, price, classification number, and serial number. The classified quarterly and annual volumes contain an alphabetical author, title and subject matter index.

The remarkable thing is that the service given is actually up-to-date. The weekly lists do in reality include all books published in the week of issue with a very few exceptions and these are never later than the previous week. The publishers, through the encouragement of the Publishers' Association (who took an active part in founding the $\mathrm{BNB}$ ), are sending their books to the copyright office in the British Museum from seven days to three weeks before publication. The BNB staff complete the cataloging of all items on the same day they are received-by doing so they clear their desks for the new lot to be received the following day.

In addition to being a great national bibliography to be used as a very valuable reference tool, enough description is given each item to enable a trained librarian to assess properly the value of the book for his library and in this way it is a most useful aid to book selection. I ts subject arrangement along lines usually found in libraries is a great help when used as an aid to build up or strengthen the book collection.

Certainly one great advantage to British libraries is BNB's use as a subject catalog. Every American who has used a number of English libraries from the subject approach knows only too well the meaning of the British phrase, "It is a bit difficult at times." Of course, the British librarians have long recognized this deficiency and some have attempted to meet the problem in various ways without too much success.

Another outstanding achievement to date of $\mathrm{BNB}$ is its central cataloging service. Each book is fully cataloged and basic material is provided for subject headings by a group of qualified catalogers. It is unfortunate that Great Britain has never had available to classifiers an accepted list of subject headings, and librarians are finding the subject index of the weekly, monthly and annual volumes of BNB a most valuable aid. Many libraries are taking advantage of this service and if not always accepting the cataloging verbatim they are at least finding the information given a very definite help when doing their own cataloging. Some libraries are finding that the annual volumes can be used as their own catalogs. It seems quite certain that this practice will spread greatly when and if $\mathrm{BNB}$ is able to carry out its plans for issuing five and perhaps ten year cumulations. It is expected that the smaller public libraries will find it desirable to use the $\mathrm{BNB}$ this way to supplement their own local catalogs which would then need to be only a shelf or stock list. Particularly in Great Britain with its well-developed national system of interlibrary lending this is possible and feasible since in reality all books in all libraries in the country are quickly and easily available to the readers of any library.

The British library profession through the National Central Library is certainly highly successful in its interlibrary loan coverage, and has a very efficient system. At present, however, the NCL's long standing policy of sending boxes of books to adult classes is not especially encouraged. The present tendency also appears to be away from NCL's attempt to own as many books as possible for loan to enlisting all of the libraries in Great Britain for help in supply- 
ing the books requested. Since the war an area-type union catalog has been undertaken by the NCL-that of Russian books in British libraries, and of German wartime and postwar publications received in Great Britain.

I believe that the $\mathrm{BNB}$ has the distinction of being discussed around the lunch table at Chaucer House more than any other topic of conversation. This fact in itself is quite a distinction since it has been my observation that the daily luncheon table discussion, presided over by Mr. P. S. J. Welsford, secretary of the Library Association, is the real place in England to become informed on the leading library problems of the country. I am sure that it is around this table that many of the ideas in the library profession in Great Britain have their origin. Sooner or later almost all of the outstanding librarians of the country will be found taking part in these informal discussions and usually they will be found there several times during the year -thus naturally it is a place where all library topics are hashed over. This daily lunch table discussion provides the headquarters staff with an opportunity to talk over matters with librarians in the field and in my estimation is a most valuable experience which is lacking at our ALA headquarters. Of course, Chaucer House, the LA headquarters, is ideally located for such informal meetings. Unlike ALA headquarters, LA is rubbing elbows with a variety of outstanding libraries. The great British Museum, the London University Library, and the National Central Library, not to mention the many special libraries associated in various ways with London University are all well within five minutes walking distance of Chaucer House. Most of the Library Association Committee meetings are held at Chaucer House and anyone, no matter where he may live in England, can quite conveniently get to London for a committee meeting. This type of contact at Chaucer House I think without doubt is a great source of inspiration to the library profession in England. I'm quite sure that Mr. Welsford, the members of his staff, and the Council have planned it this way and the fact of being centrally located in a small country is not the only contributing element. They have arranged a comfortable and attractive lounge known as "The Members' Room" and in this room have provided luncheon quarters serving full course meals and have encouraged members from near and far to make use of the room. In fact they find this get-together over the luncheon table so valuable to the profession that in order to help attract members the price of the food has been made very reasonable, even to the extent of the association subsidizing the meals when it becomes necessary. The results are that the headquarters staff definitely have a most valuable fellowship contact with members in the field, the like of which I never experienced during my three years at 5o East Huron St.

Perhaps the U.S.A. is too large to accomplish anything approximating this fellowship at the headquarters of its national library association unless someday we have two or three regional headquarters. There does seem, however, to be a center in the process of developing around the University of Chicago now that the Midwest InterLibrary Center is there, and in time that location might prove to be a great advantage over the present ALA headquarters, especially for ACRL. It is possible, of course, that this luncheon club effect at Chaucer House is just a part of the English club approach which is such a pleasant aspect of English life. Whatever the reasons may be for its existence it has become an institution 
at Chaucer House and it is something that the Library Association, I am sure, will always keep and cherish, and which the ALA headquarters might well try to emulate.

The BNB has even revolutionized the appearance of the British Museum by introducing the card catalog. When I first used the British Museum in 1937 I found nothing in it that resembled a card catalog. However, when I entered its great reading room in September 1952, one of the first sights that met my eyes was a large section of card catalog cabinets. The newly decorated reading room of the British Museum with its modern individual fluorescent lighting fixtures; the leather covered tables and most comfortable arm-chairs on casters; the unique individual folding book-rests which recede, when not in use, into the center partition found at most of the tables (this high partition provides a private atmosphere so much sought after in American libraries today); the busy activities of the BNB; the office of the Friends of National Libraries; the headquarters of the British Union Catalog of Periodicals; and the first few minutes in the office of Mr. F. C. Francis, Keeper, Department of Printed Books listening to some of Mr. Francis' ideas about the future development and activities of large research libraries all give the impression that great things are happening in the British Museum and that many progressive steps will be forthcoming from that library. One has the feeling that in recent years the British Museum is taking a cue from the Library of Congress and is not concerned so much with its own scholarly development but is assuming a more healthy outward look and in some cases taking the lead rather than detaching itself from most library movements in the country.

It appears that the real emphasis behind the BNB came from the Library Association but the British Museum, influenced by UNESCO's drive for national bibliographies, was the first spark for making it a reality. It was necessary to set up the BNB office in the British Museum where access could be had to all of the copyright books in Great Britain. Therefore office space was given $\mathrm{BNB}$ in an adjoining building belonging to the British Museum. It was interesting, however, to note that the only way the BNB could obtain permission to have the British Museum's deposited copyright books delivered to their office was to transfer them in locked boxes, and if it became necessary to keep them over night Mr. Wells had to agree to put them under lock and key. One is greatly impressed with the determination of Mr. Wells and his staff to overcome every obstacle that may be in the way of the growth and development of BNB.

The British Museum has also fostered, at least to the extent of providing office space, two other organizations-the British Union Catalog of Periodicals and the Friends of National Libraries.

The Union Catalog of Periodicals project has been handicapped in that it has had three different editors since its inception and at present is having financial difficulties. It was the plan of the original editor to include great masses of material such as administrative annual reports of all kinds of bodies throughout the world, documents issued by the central and local government departments of all countries, local directories and guides, timetables, and other miscellaneous items in great variety. This undertaking has been abandoned and the information has been turned over to the National Central Library. It is hoped that funds will be available for publishing the catalog when it is completed but in any case its constitution states "Should the publication of the 
catalog prove impossible, the material collected shall be given to the Trustees of the National Central Library, for use in such a way as will best supplement their records of periodicals in English libraries." However, every effort is being made to insure its publication.

The British have great feeling for their national treasures and are doing a fine job of keeping and preserving them. The Friends of the National Libraries, which assists the national, university, and municipal libraries, is enthusiastically supported. Of course the U.S. is too large a nation to organize a "Friends" group for the entire country as has been done in Great Britain, and probably should continue to concentrate on Friends of individual libraries. However, we might well take a suggestion from the British and organize state groups in order to help keep within state borders the literary and historical heritage of each state.

Future contemplated activities of BNB include analytical entries for articles in periodicals prepared perhaps with the aid of university, special and reference libraries of the country; a British index of subject headings; directions for classified cataloging; a national bibliography of music; and possibly a card service for those libraries having card catalogs.

Some of the libraries in America already subscribing to the English Catalog of Books and/or Whitaker's Cumulative Book List may feel that they cannot afford BNB as well. $\mathrm{BNB}$ has several advantages over these two publications-it has a classified subject arrangement, a wider scope, a much fuller entry, and a more up-to-the-minute list of books being published in England thus giving American libraries a better opportunity to obtain copies before they go out of print-a disappointment experienced by so many in recent years. It is possible and desirable when placing orders with book dealers in London to order by the serial number given in the $\mathrm{BNB}$ just as LC cards are now ordered by the LC number.

It would appear that libraries in the U.S. buying books published in Great Britain should do more of their ordering direct from English dealers. The English dealers are prepared to give quicker service and should be able to allow the purchasing library a greater discount than can be received from agents in America. By using the BNB serial number a large book order could be sent by air mail for only ro $\phi$ and at the same time reduce the amount of paper work necessary when using author, title, etc.

I would point out Mr. W. J. McEldowney's article in the New Zealand Libraries for July I95 I to those libraries who may feel that the Cumulative Book Index will meet their need for English books. Mr. McEldowney states that in comparing an issue of the $\mathrm{BNB}$ with the $\mathrm{CBI}$ - "there are 335 items listed in this issue of the $\mathrm{BNB}$, of which fewer than half had made the CBI by nearly nine months later."

\section{"Socialistica" of I800-1850}

\section{(Continued frım page 404)}

collectors is still small, perhaps less than two dozen. But also few in number are the dealers who specialize in "socialistica," so that the supply by no means equals the demand. All in all, this is a subject which can be recommended to most librarians. There is competition enough to challenge the combative, and opportunity enough to sustain those who require occasional encouragement. 